\title{
2011 Souris River Flood-Will it Happen Again?
}

By taking into consideration historical climate record and trends in basin response to various climatic conditions, it was determined flood risk will remain high in the Souris River Basin until the wet climate state ends. During a wet climate state there is about a 0.2-percent chance, in any given year, that there will be another flood like the 2011 flood (or greater). In other words, if the current wet climate state continues during the next 10 years, there is about a 2-percent chance that there will be another flood like the 2011 flood (or greater). Specifically, when looking at Rafferty Reservoir (the primary flood-control structure for downstream communities), there is a 3-percent chance in any given year that the annual capacity will be exceeded. This means that if the wet climate state continues during the next 10 years, there is about a 30-percent chance Rafferty's annual capacity will be exceeded.

\section{Introduction}

The Souris River Basin is a 61,000 square kilometer basin in the provinces of Saskatchewan and Manitoba and the state of North Dakota (fig. 1). Record setting rains in May and June of 2011 led to record flooding with peak annual streamflow values (762 cubic meters per second $\left.\left[\mathrm{m}^{3} / \mathrm{s}\right]\right)$ more than twice that of any previously recorded peak streamflow and more than five times the estimated 100 year postregulation streamflow $\left(142 \mathrm{~m}^{3} / \mathrm{s}\right)$ at the U.S. Geological Survey (USGS) streamflow-gaging station above Minot, North Dakota.

Upstream from Minot, N. Dak., the Souris River is regulated by three reservoirs in Saskatchewan (Rafferty, Boundary, and Alameda) and Lake Darling in North Dakota (figs. 1 and 2). During the 2011 flood, the city of Minot, N. Dak., experienced devastating damages with more than 4,000 homes flooded and 11,000 evacuated (fig. 3). As a result, the Souris River Basin Task Force recommended the U.S. Geological Survey (in cooperation with the North Dakota State

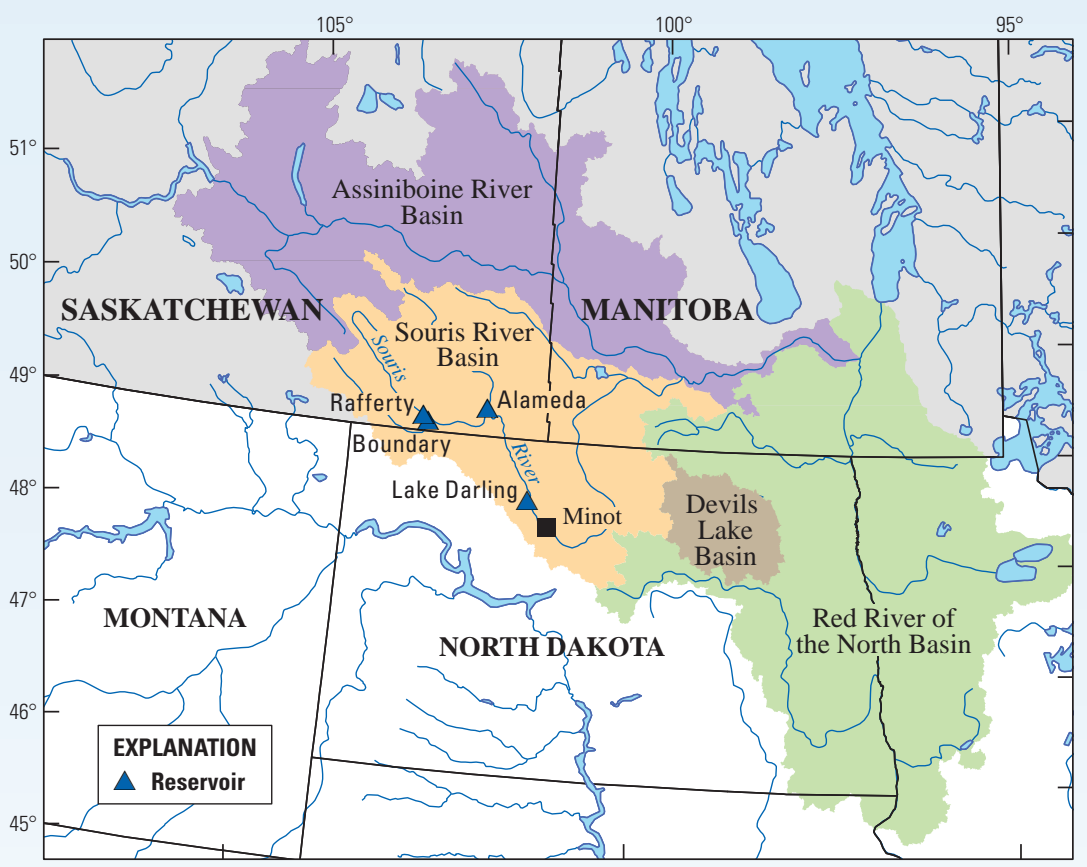

Figure 1. Souris River Basin in respect to the Assiniboine, Devils Lake, and Red River of the North Basins.
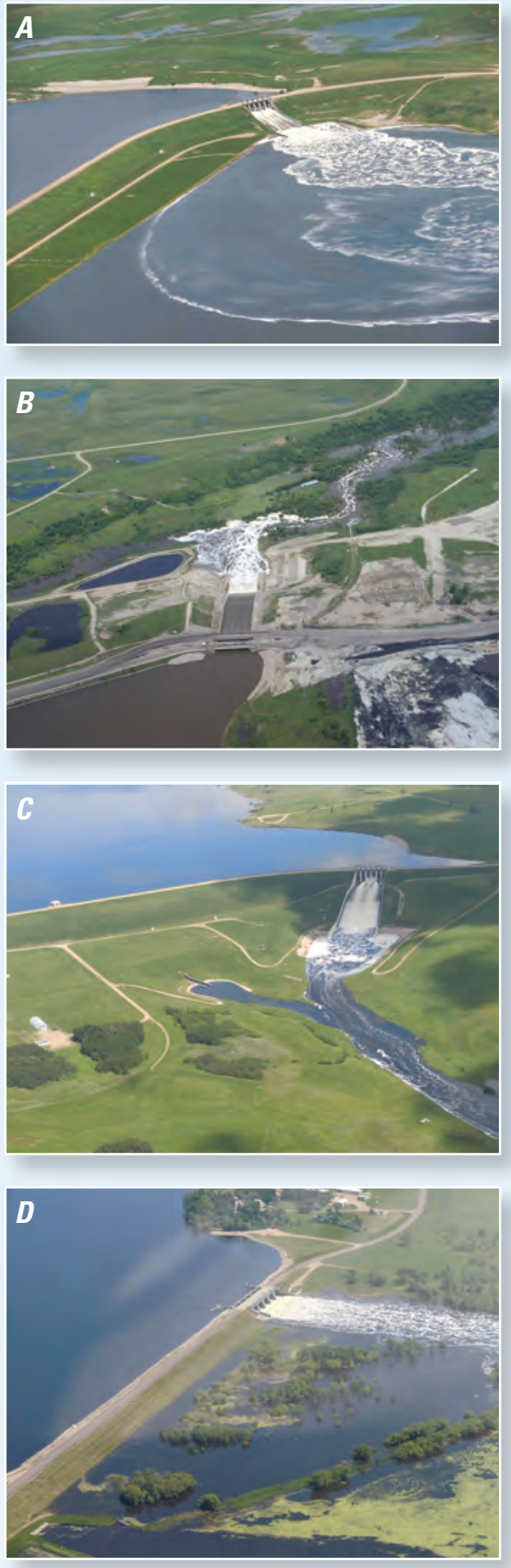

Figure 2. Four reservoirs on the Souris River upstream from Minot, North Dakota, June 23, 2011. $A$, Rafferty Reservoir, regulation began in 1991; $B$, Boundary Reservoir, regulation began in 1958; C, Alameda Reservoir, regulation began in 1992; $D$, Lake Darling Reservoir, constructed in 1936. 


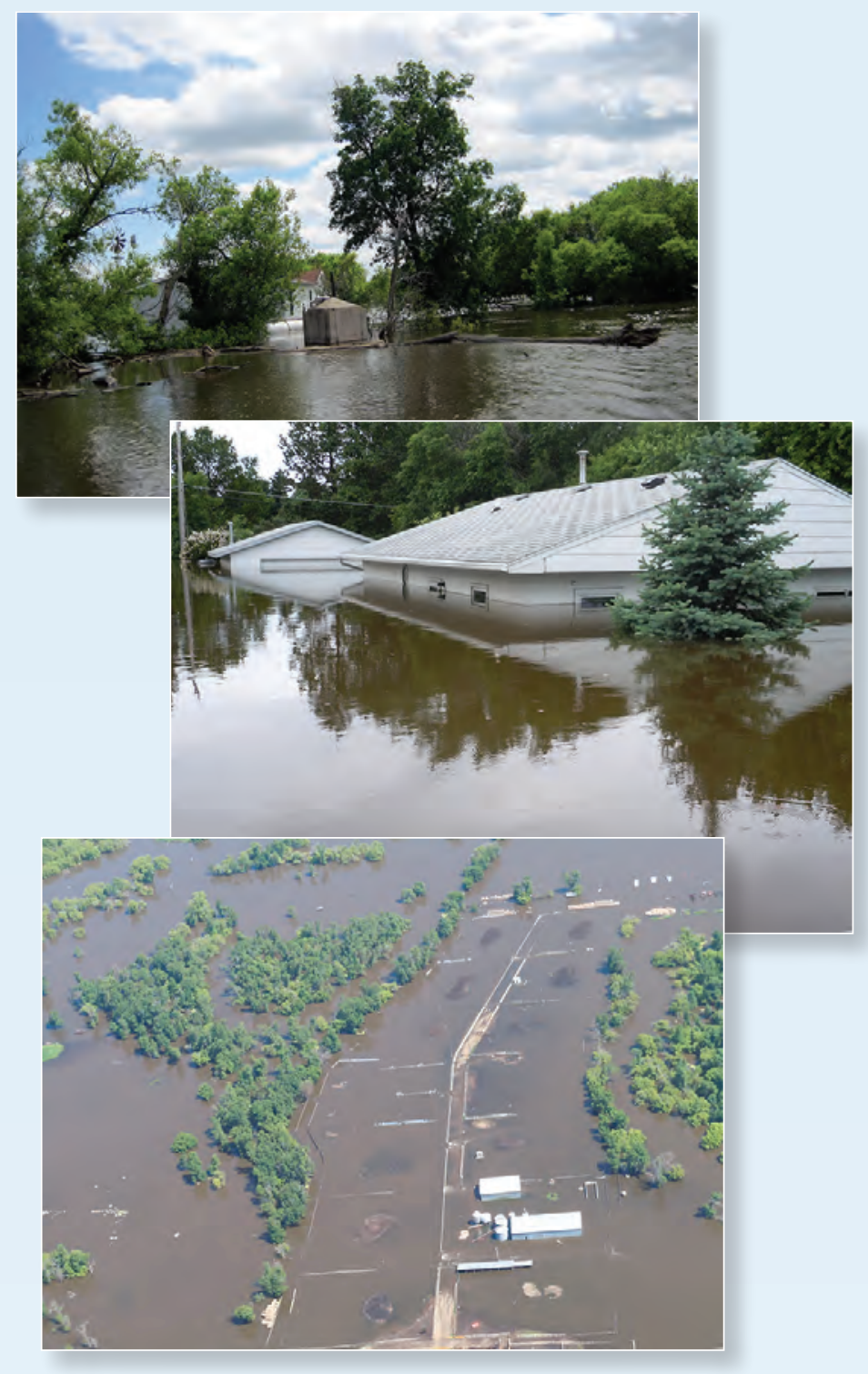

Figure 3. Souris River flooding in 2011.

Water Commission) develop a model for estimating the probabilities of future flooding and drought. The model that was developed took on four parts: (1) looking at past climate, (2) predicting future climate, (3) developing a streamflow model in response to certain climatic variables, and (4) combining future climate estimates with the streamflow model to predict future streamflow events.

\section{Looking at Past Climate}

Tree-ring data, in combination with statistical analysis, were used to extend historical precipitation records further into the past (Ryberg and others, 2016). This type of analysis is also referred to as hindcasting. For the hindcasting, five distinct clusters of meteorological stations (based on similar precipitation) were used to extend the precipitation record back to the early 1700s (fig. 4).

Runoff is highly dependent on the season in the Souris River Basin, so three 4-month seasons were used in the analysis: season 1 (November-February), season 2 (March-June), and season 3 (July-October). For cluster 5, season 3, a shift toward higher summer and fall precipitation can be seen in the late 1970s (fig. 5). This shift has been documented in a number of previous studies (Garbrecht and Rossel, 2002; Shapely and others, 2005; Vecchia, 2008; Small and Islam, 2008).

\section{Predicting Future Climate}

Use of the extended precipitation records from the treering analysis, along with recorded meteorological data, led to the development of a statistical climate simulation model, called a stochastic climate model, to predict future climatic conditions such as precipitation, temperature, and potential evapotranspiration (combination of evaporation and transpiration from plants).

From the statistical analysis, a significant transition (called a step trend) was identified in the precipitation record around 1970, with 1912-69 representing a dry climate state and 1970-2011 representing a wet climate state. This is consistent with the nearby Devils Lake Basin in northeastern North Dakota (fig. 1), which shows evidence of alternating states between "wet" and "dry" (Vecchia, 2008).

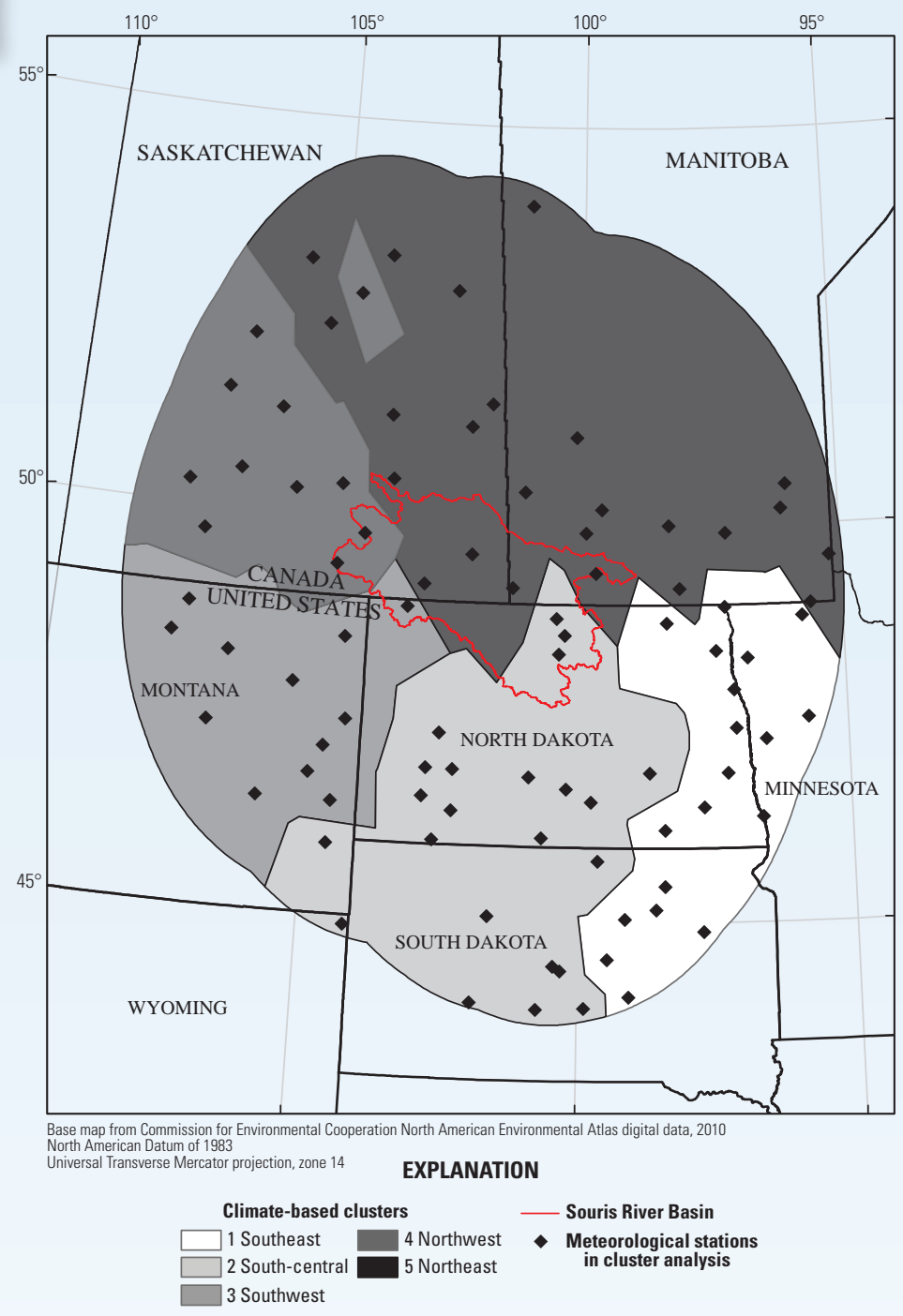

Figure 4. Five clusters of meteorological stations used in treering analysis. 


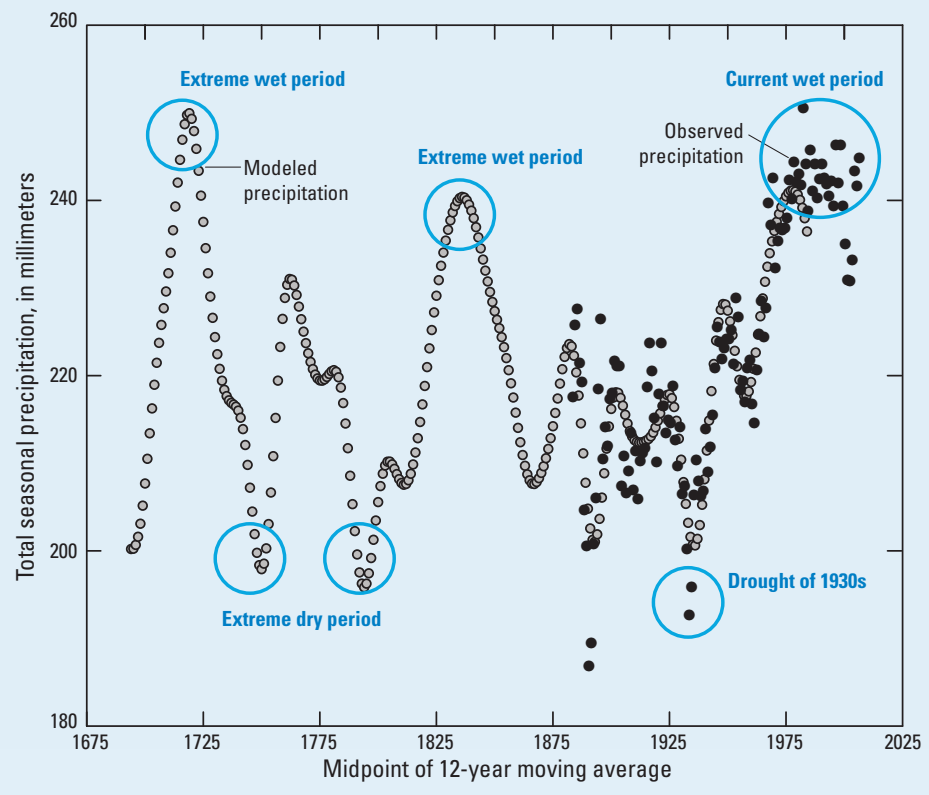

Figure 5. Modeled and observed 12-year moving average precipitation for area representing southern Manitoba and southeastern Saskatchewan for season 3 (July-October).

\section{Streamflow Model}

A water balance model was developed to convert climatic data, provided through the stochastic climate model, to monthly natural streamflow estimates. Natural streamflow, or unregulated streamflow, means the effects of Alameda, Rafferty, Boundary, and Lake Darling reservoirs were removed and streamflow was allowed to flow through the basin as it would have before the four reservoirs were installed. The water-balance model takes into account water entering the system (rain and snow) and leaving the system (runoff, subsurface flow, and evapotranspiration) to estimate the amount of water contributing to streamflow (fig. 6). A flow routing model was then used to route flows through the Souris River Basin.

\section{Will it Flood Again?}

Of particular interest is the likelihood that there will be another flood similar to or more extreme than the 2011 flood. To determine this, the likelihood of extreme climatic events (stochastic climate model) and how the Souris Basin responds to extreme climatic events (water-balance and flow-routing models) were combined into a stochastic streamflow model.

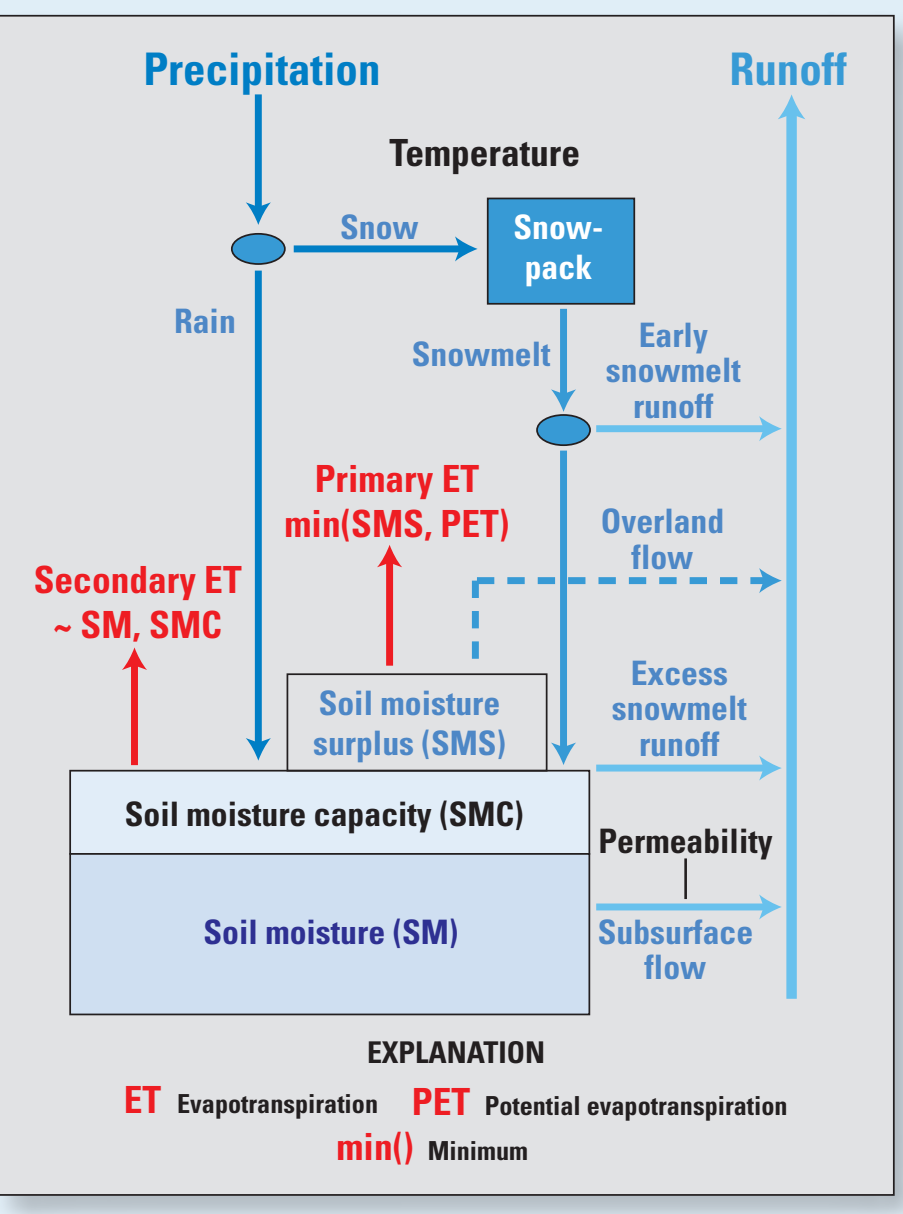

Figure 6. Schematic of the water-balance model.

The stochastic streamflow model was used to generate 100 potential future streamflow traces, each 100 years in duration, or 10,000 simulation-years of data. An example 100-year potential future streamflow trace generated through the stochastic streamflow model is shown in figure 7. In this simulation, the wet climate state (similar to 1970-2011) continues for an additional 50 years and then transitions to the dry climate state.

The data were then used to develop flood-frequency curves, which provide the probability of a certain flood event happening in any given year. Flood-frequency curves are generally considered to be stationary, which means the flood probabilities are the same year-after-year. Another way of stating this is that climate and streamflow conditions are assumed to be in an "equilibrium" state; however, the alternating wet and dry climate states in the

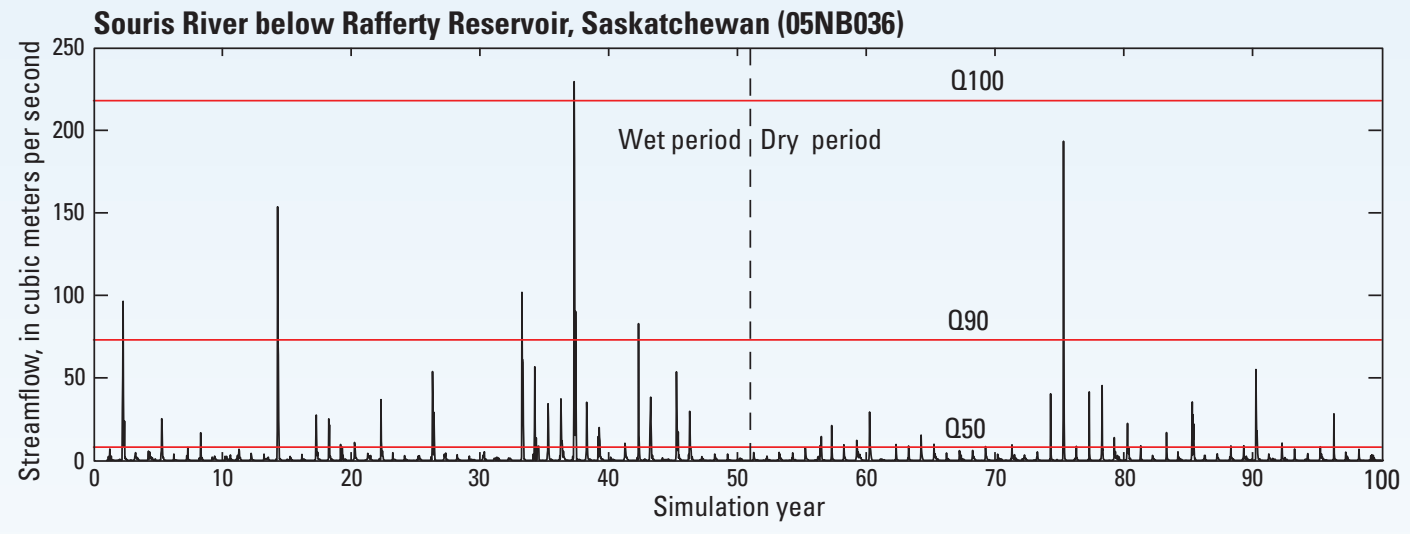

Figure 7. Simulated 10-day mean streamflow for 100-year simulation period ( 50 years of wet climate state followed by 50 years of dry climate state) for the Souris River below Rafferty Reservoir, Saskatchewan (05NB036) streamflow-gaging station as compared to the median (050), 90th percentile (090), and maximum $(0100)$ values of annual maximum natural 10-day streamflow. 


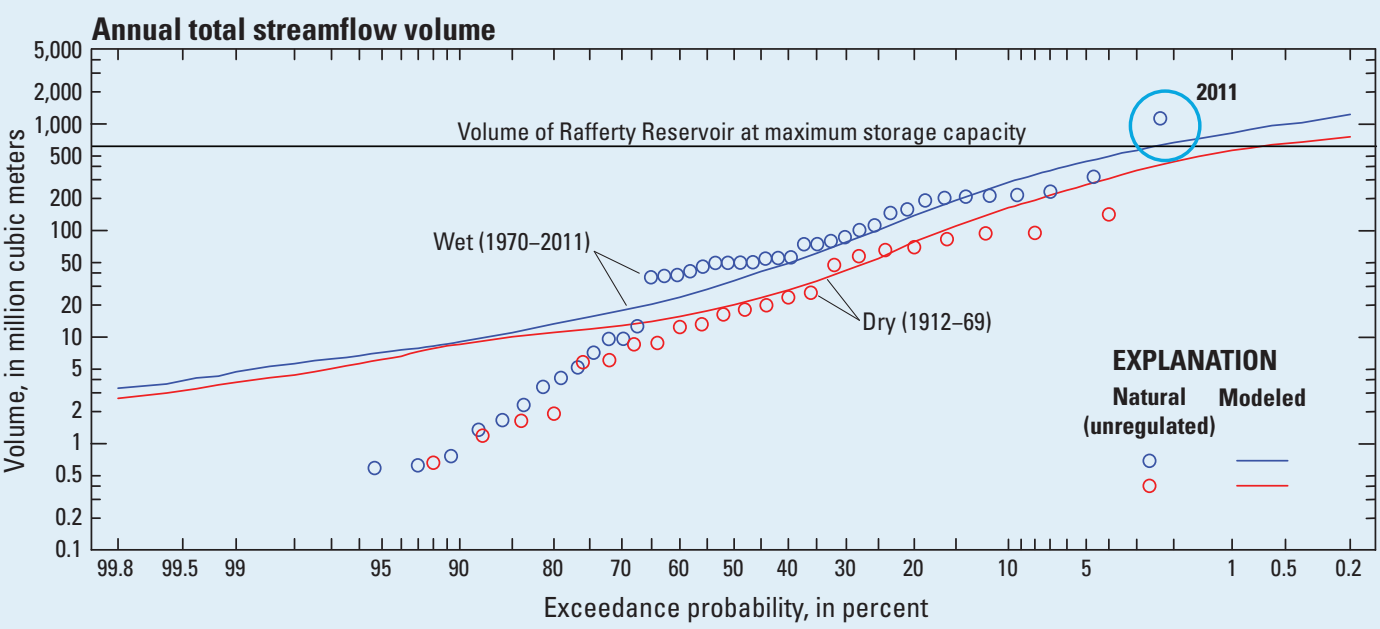

Figure 8. Equilibrium frequency distributions for the Souris River below Rafferty Reservoir, Saskatchewan (05NB036), streamflow-gaging station for wet (1970-2011) and dry (1912-69) climate states.

Souris River Basin imply there are two equilibrium flood-frequency curves: one for the wet state and one for the dry state.

The two equilibrium flood-frequency curves computed using the model simulations, as well as points showing the available observed natural streamflow values from the two climate periods, are shown in figure 8 . This site represents inflows to Rafferty Reservoir, for which annual total flow volumes are more important than instantaneous peak flows. In 2011 (represented by the highest blue point), annual total inflow was about twice the reservoir storage capacity (633 million cubic meters), spillways were discharging at full capacity, and the reservoir was unable to control subsequent outflow.

If the current wet climate state (fig. 8, blue line) continues, there is a 3-percent chance in any given year inflows to Rafferty Reservoir will exceed the 633 million cubic meter capacity of Rafferty Reservoir. This means if the wet climate state continues during the next 10 years, there is about a 30 -percent chance annual inflows to Rafferty Reservoir will exceed reservoir capacity at least once. There is about a 0.2 -percent chance, in any given year, that there will be another flood like the 2011 flood (or greater) (fig. 8). In other words, if the wet climate state continues during the next 10 years, there is about a 2-percent chance that there will be another flood like the 2011 flood (or greater). Past data indicates the wet climate state will revert back to the dry climate state, but when that will happen is uncertain.

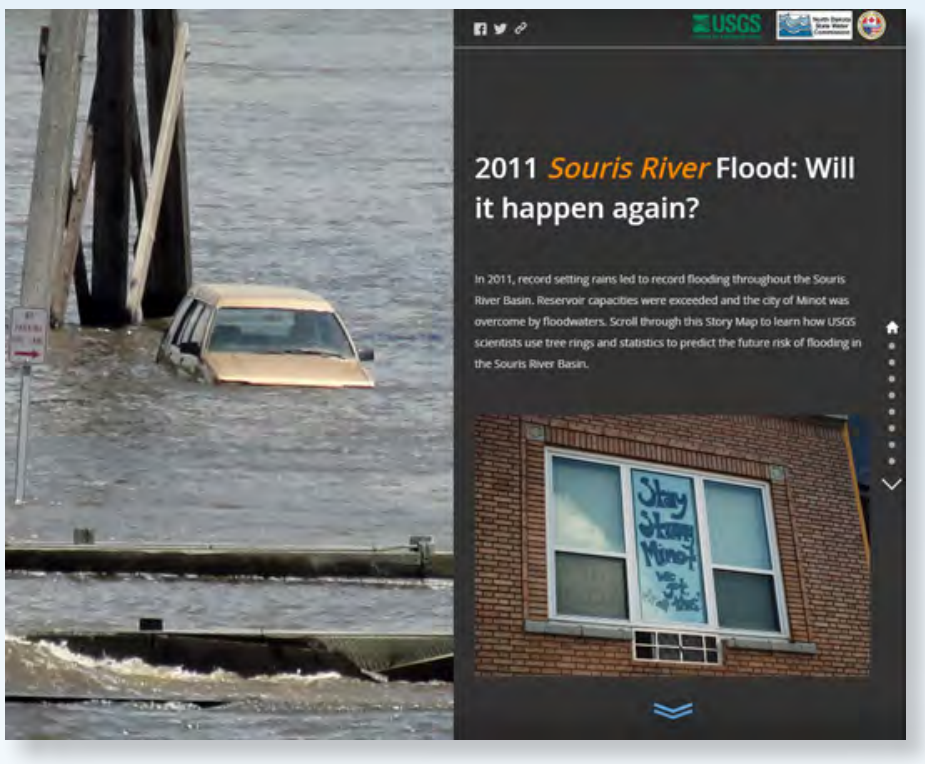

Figure 9. Screenshot of story map Web page.

\section{References Cited}

Garbrecht, J.D., and Rossel, F.E., 2002, Decade-scale precipitation increase in Great Plains at end of 20th century: Journal of Hydrologic Engineering, v. 7, no. 1, p. 64-75.

Kolars, K.A., Vecchia, A.V., and Ryberg, K.R., 2016, Stochastic model for simulating Souris River Basin precipitation, evapotranspiration, and natural streamflow: U.S. Geological Survey Scientific Investigations Report 2015-5185, 55 p. [Also available at http://dx.doi.org/10.3133/sir20155185.]

Ryberg, K.R., Vecchia, A.V., Akyüz, F.A, and Lin, W., 2016, Tree-ring-based estimates of long-term seasonal precipitation in the Souris River Region of Saskatchewan, North Dakota and Manitoba: Canadian Water Resources Journal. [Also available at http://dx.doi.org/10.1080/07011784.2016.1164627.]

Shapely, M.D., Johnson, W.C., Engstrom, D.R., and Osterkamp, W.R., 2005, Late-Holocene flooding and drought in the Northern Great Plains, USA, reconstructed from tree rings, lake sediments, and ancient shorelines: The Holocene, v. 15, p. 29-41.

Small, David, and Islam, Shafiqul, 2008, Low frequency variability in fall precipitation across the United States: Water Resources Research, v. 44, no. 4, 13 p.

Vecchia, A.V., 2008, Climate simulation and flood risk analysis for 2008-40 for Devils Lake, North Dakota: U.S. Geological Survey Scientific Investigations Report 2008-5011, 28 p., accessed June 23, 2015, at http://pubs.usgs.gov/ sir/2008/5011/.

\section{Further Information}

An interactive story map, illustrating the content discussed here, has been developed and is available here: http://ijc.maps. arcgis.com/apps/MapJournal/index.html?appid=85824fb350394 d75919d1826befb57e8.

This fact sheet summarizes information presented in Kolars and others (2016). 